\title{
Pengaruh Berbagai Media Tanam Dan Pemberian Mikro Organisme Lokal (MOL) Keong Mas Terhadap Pertumbuhan Dan Produksi Tanaman Bawang Tiwai (Eleutherine americana)
}

\section{Influence of Various Growing Media And Local administration of Micro-organisms (MOL) Keong Mas To Growth And Production Plant Onions Tiwai (Eleutherine americana)}

\author{
Sumarno ${ }^{1}$, Mahdalena ${ }^{2}$ dan Hamidah ${ }^{2}$ \\ ${ }^{1}$ Alumni Program Studi Agroteknologi, Fakultas Pertanian, Universitas Widya Gama Mahakam \\ Jl. KH. Wahid Hasyim, Sempaja, Samarinda, Kalimantan Timur, Indonesia. \\ ${ }^{2}$ Tenaga Pendidik Program Studi Agroteknologi, Fakultas Pertanian, Universitas Widya Gama Mahakam \\ Jl. KH. Wahid Hasyim, Sempaja, Samarinda, Kalimantan Timur, Indonesia. \\ email : sumarnomarno@yahoo.com, mahda.amin@yahoo.com, hamidah@uwgm.ac.id
}

Diterima : 17 Oktober 2016 Disetujui : 2 November 2016

\begin{abstract}
Onions Tiwai is one plant in Borneo forest used by people as a traditional medicine. One of the efforts to support increased production of onions tiwai is through the cultivation of technology media including by the use of appropriate planting and the provision of the Micro Organisms Local (MOL). The aim of research to know the influence of MOL conch mas on growth and yield of onion tiwai and to determine the best planting medium for the growth and production of onions tiwai. The study was conducted over four months starting from nursery seedlings until harvest. This study uses a randomized block design (RBD) with a $4 \times 4$ factorial experiment consisting of three replications. The first factor is the Growing Media which comprises four levels: ie m0 (Control), ml (Topsoil and sand), m2 (Topsoil and Rice Husk) and m3 (Topsoil, Rice Husk and Sand). The second factor is the concentration of microorganisms Local (MOL) snails consists of four levels ie p0 (control) pl (100 ml / liter water) p2 (200ml / liter of water) and p3 (300 $\mathrm{ml} /$ liter). The results showed that treatment of the planting medium (M) significantly affected the parameters of the number of leaf age 60 DAP and is not significantly affected, plant height, number of tillers, the number of bulbs, tubers and the weight of the growing media $\mathrm{pH}$. While the provision of MOL Keong Mas $(P)$ had no significant effect on all parameters. There is no interaction between the treatment plant and the provision of various media MOL Keong Mas on all parameters observed.
\end{abstract}

Key words: Onion tiwai, planting media and MOL keong mas

\section{PENDAHULUAN}

Bawang Tiwai (E. americana) merupakan tumbuhan di hutan Kalimantan yang biasa digunakan oleh masyarakat pedalaman menjadi ramuan atau obat tradisional. Bulbus tumbuhan genus Eleutherine ini dari beberapa penelitian diketahui mengandung senyawa metabolit sekunder golongan naftokuinon (elecanacin, eleutherin, elutherol, eleutherinon) (Kuntorini, 2013). Berbagai jenis tumbuhan telah dimanfaatkan oleh masyarakat sebagai obat tradisional, salah satu diantaranya adalah bawang tiwai atau bawang dayak yang dimanfaatkan oleh masyarakat pedalaman suku Dayak di pulau Kalimantan secara turuntemurun sebagai obat tumor dan kanker (Suroto dkk, 2006).

Kemajuan ilmu pengetahuan dan teknologi membuktikan bahwa bawang tiwai banyak mengandung berbagi bahan kimia aktif, diantaranya senyawa golongan kimia alkaloid, steroid, triterpenoid, protein, saponin, karbohidrat dan senyawa-senyawa lainnya, yang telah dimanfaatkan oleh masyarakat modern sebagai obat sembelit, kanker, peluruh air seni, urus-urus dan memperlancar air susu ibu
(Saptowalyono, 2008). Ketersediaan bawang tiwai yang tidak mencukupi, padahal tersedia potensi lahan yang cukup untuk mengembangkan tanaman tersebut. Mengingat jumlah penduduk Indonesia dari tahun ke tahun terus bertambah. Sehingga kebutuhan bahan tumbuhan berupa obat dan gizi masyarakat juga meningkat. Sementara budidaya tanaman obat belum mencukupi kebutuhan masyarakat (Laporan Pengembangan Wilayah, 1999).

Wilayah Kalimantan Timur khususnya Samarinda memiliki jenis tanah ultisol (Bappeda Kota Samarinda, 2015). Ditambahkan oleh Hardjowigeno (2007), berdasarkan kondisi tanah Kalimantan Timur tergolong ultisol, yaitu tanahtanah tempat terjadinya penimbunan liat atau dikenal juga sebagai podsolik merah kuning. Pada tanah ultisol memiliki karakter tanah yang tidak optimal dimana berstruktur liat, dengan kejenuhan basa rendah, kadar $\mathrm{Al}$ yang tinggi, kadar unsur hara yang rendah merupakan penghambat utama untuk pertanian (Hardjowigeno, 2007). Dengan kondisi yang liat tersebut diupayakan pemberian bahan organik berupa pupuk organik yang diberikan pada tanah untuk memperbaiki struktur dan tata tanah, udara tanah sehingga penyerapan unsur hara 
oleh akar tanaman menjadi lebih baik dan meningkatkan daya sanggah air.

Untuk meningkatkan pertumbuhan hasil produksi tanaman membutuhkan kandungan unsur hara yang cukup. Salah satu upaya untuk meningkatkan unsur hara adalah dengan pemberian Mikroorganisme Lokal (MOL). Menurut Mulyono (2014), Mikroorganisme Lokal (MOL) merupakan mikroorganisme hasil fermentasi dari bahan yang ada di lingkungan sekitar dan mudah didapat. Penggunaan bahan bakunya disesuaikan dengan potensi di suatu wilayah.

Kandungan unsur hara dalam MOL mempunyai kelengkapan unsur hara yang lengkap. Meskipun unsur haranya dalam jumlah sedikit, tetapi seluruh kebutuhan unsur hara mikro dan makro bagi tanaman dapat terpenuhi. Unsur tersebut diantaranya $\mathrm{N}, \mathrm{P}, \mathrm{K}, \mathrm{Ca}, \mathrm{Mg}, \mathrm{S}$, $\mathrm{Mn}, \mathrm{Fe}, \mathrm{Cu}, \mathrm{Zn}, \mathrm{Mo}$, dan Bo. Selain kandungan unsur hara yang lengkap MOL dapat digunakan sebagai starter atau dekomposer, mikroorganisme lokal (MOL) juga dapat digunakan sebagai pupuk hayati, pestisida organik dan fungisida dengan dosis yang sangat kecil (Mulyono, 2014).

Usaha lain untuk memperoleh pertumbuhan dan hasil yang tinggi perlu dilakukan

\section{BAHAN DAN METODE}

Penelitian ini dilaksanakan selama 4 bulan, mulai dari bulan Mei sampai dengan September 2015, tempat penelitian di lokasi PT. Wana Nusa Perkasa Seberang Samarinda Provinsi Kalimantan Timur. Bahan yang digunakan umbi bawang tiwai, Mikroorganisme Lokal (MOL) (keong mas, gula merah, air cucian beras dan air kelapa), sekam padi, pasir sungai, topsoil, pestisida (Furadan 3G). Penelitian ini menggunakan Rancangan Acak Kelompok (RAK) dengan percobaan faktorial $4 \times 4$ yang terdiri dari 3 ulangan. Faktor pertama adalah media tanam (M) yang terdiri dari 4 taraf, yaitu : m0 (topsoil (kontrol), $\mathrm{m}_{1}$ ( topsoil + pasir (1:1)), $\mathrm{m}_{2}$ (topsoil + sekam padi (1:1)) dan $\mathrm{m}_{3}$ (topsoil + pasir + sekam padi (1:1:1)) dan faktor

\section{HASIL DAN PEMBAHASAN}

\section{Pengaruh Perlakuan Media Tanam}

Hasil analisis sidik ragam menunjukan perlakuan media tanam tidak berpengaruh nyata terhadap parameter tinggi tanaman $(\mathrm{cm})$, jumlah anakan, jumlah umbi pertanaman (rumpun), berat umbi pertanaman (rumpun) dan $\mathrm{pH}$ media tanam, namun berpengaruh nyata terhadap parameter jumlah daun 60 HST ( umur 2 bulan). penggunaan media tanam yang baik. Media tanam yang ideal jika terdapat keseimbangan unsur hara serta komposisi dan strukturnya baik sehingga tanaman dapat tumbuh opimal karena cukup tersedia unsur hara bagi tanaman.

Penggunaan media tanam yang tepat akan menentukan pertumbuhan bibit yang ditanam. Secara umum media tanam yang digunakan haruslah mempunyai sifat yang ringan, murah, mudah didapat, gembur dan subur, sehingga memungkinkan pertumbuhan bibit yang optimum (Erlan, 2005 dalam Tambunan, dkk. 2014)

Menurut hasil penelitian Tambunan, dkk (2014) bahwa pemberian berbagai komposisi media tanam berpengaruh nyata terhadap parameter : tinggi tanaman, jumlah anakan, jumlah daun, bobot basah umbi per sampel, bobot kering umbi per sampel, bobot basah umbi per plot, bobot kering umbi per plot, kecuali pada jumlah siung per sampel.

Berdasarkan uraian tersebut, maka perlu dilakukan penelitian untuk menguji pengaruh berbagai media tanam dan pemberian mikroorganisme lokal (MOL) keong mas terhadap pertumbuhan dan produksi tanaman bawang tiwai (E. americana).

kedua adalah pemberian konsentrasi MOL yang terdiri dari 4 taraf, yaitu : p0 $(0 \mathrm{ml} /$ liter air $), \mathrm{p}_{1}$ $=100 \mathrm{ml} /$ liter air/ tanaman, $\mathrm{p}_{2}(200 \mathrm{ml} /$ liter air/ tanaman) dan $\mathrm{p}_{3}$ (300 ml/liter air/ tanaman). Pelaksanaan meliputi : persiapan lahan, persiapan bibit, pembuatan MOL, penyiapan media tanam, penanaman, Aplikasi MOL, pemeliharaan tanaman (penyiraman, penggantian tanaman, penyiangan, pengendalian hama) panen. Pengambilan data meliputi : tinggi tanaman, jumlah daun, jumlah anakan, jumlah umbi pertanaman, berat umbi pertanaman dan ph media tanam. Data yang ada dianalisis dengan sidik ragam untuk melihat pengaruh perlakuan. Hasil sidik ragam yang menunjukkan pengaruh maka untuk membandingkan rata-rata perlakuan dilakukan Uji BNT dengan taraf 5\%.

Media tanam tidak berpengaruh nyata terhadap parameter pertumbuhan yakni tinggi tanaman, jumlah anakan dan parameter produksi yaitu berat umbi dan jumlah umbi. Hal ini diduga media tanam hanya berperan sebagai tempat berpijaknya akar tanaman namun tidak mampu menyuplai kebutuhan unsur hara yang dibutuhkan oleh tanaman.

Perlakuan media tanam dengan menggunakan perbandingan topsoil dan pasir, topsoil dan sekam padi serta topsoil, sekam padi 
dan pasir tidak menyediakan unsur hara untuk tanaman bawang tiwai, hal ini dapat dilihat dari peran sekam padi dan pasir yang secara umum berperan dalam memperbaiki struktur tanah sehingga sistem aerasi dan drainase menjadi baik. Sesuai dengan pernyaataan Redaksi PS (2007) sekam padi bakar dan sekam padi mentah memiliki tingkat porositas yang sama. Sebagai media tanam keduanya berperan penting dalam perbaikan struktur tanah sehingga sistem aerasi dan drainase di media tanam menjadi lebih baik. Kelebihan dari sekam mentah sebagai media tanam yaitu mudah mengikat air, tidak mudah lapuk dan tidak mudah menggumpal atau memadat sehingga akar tanaman tumbuh dengan sempurna. Namun sekam padi mentah cenderung miskin unsur hara. Sehingga diasumsikan rendahnya kandungan unsur hara yang terdapat dalam media tanam tidak mampu memenuhi kebutuhan unsur hara tanaman bawang tiwai untuk pertumbuhan.

Menurut Redaksi PS (2007) unsur hara merupakan faktor yang mutlak dibutuhkan oleh tanaman untuk melengkapi daur hidupnya, mulai dari fase vegetatif sampai generatif. Unsur-unsur tersebut menjadi bagian dari pertumbuhan tanaman yang penting, karenanya disebut sebagai unsur hara esensial.

Tabel 1. Jumlah daun (helai) pada perlakuan media tanam

\begin{tabular}{cccc}
\hline \multirow{2}{*}{ Media tanam } & \multicolumn{3}{c}{ Jumlah daun (helai) } \\
\cline { 2 - 4 } & 30 hst & 60 hst & 90 hst \\
\hline m0 & 6,67 & $34,08 \mathrm{a}$ & 64,08 \\
$\mathrm{~m} 2$ & 5,58 & $36,50 \mathrm{a}$ & 66,58 \\
$\mathrm{~m} 3$ & 6,33 & $20,17 \mathrm{~b}$ & 53,67 \\
& 5,00 & $19,50 \mathrm{~b}$ & 57,67 \\
\hline
\end{tabular}

Keterangan : Angka-angka yang diikuti huruf yang sama menunjukkan tidak berbeda nyata pada uji BNT 5\%

Perlakuan media tanam tidak berpengaruh nyata terhadap parameter yang diamati kecuali pada parameter jumlah daun umur 60 HST. Namun secara berturut-turut pelakuan m1 (Topsoil \& Pasir) menunjukan pertumbuhan dan

\section{Pengaruh Perlakuan Mikroorganisme Lokal (MOL) Keong Mas}

Hasil analisis sidik ragam menunjukan perlakuan Mikroorganisme Lokal (MOL) keong mas tidak berpengaruh nyata terhadap parameter tinggi tanaman $(\mathrm{cm})$, jumlah daun, jumlah anakan, jumlah umbi pertanaman, berat umbi pertanaman dan $\mathrm{pH}$ media tanam.

Pemberian Mikroorganisme Lokal (MOL) keong mas tidak berpengaruh nyata terhadap parameter pertumbuhan yaitu tinggi tanaman, jumlah daun, dan jumlah anakan. Hal ini diduga kandungan unsur hara yang terdapat pada MOL relatif kecil yaitu sekitar $\mathrm{N}$ total $0,15 \%, \mathrm{P} 205$ $0,10 \%$ dan $\mathrm{K}_{2} \mathrm{O} \quad 0,153 \%$ sehingga belum mampu memenuhi kebutuhan unsur hara yang dibutuhkan oleh tanaman bawang tiwai. Sesuai dengan pernyataan Sutedjo (2008) tanaman memerlukan unsur hara yang cukup untuk melangsungkan proses fisiologisnya.

Pemberian Mikroorganisme Lokal (MOL) keong mas tidak berpengaruh nyata terhadap parameter produksi. Hal ini diduga kandungan unsur hara yang terkandung dalam MOL keong mas relatif sedikit karena bahan membuat MOL yang terdiri dari keong mas, gula merah, air cucian beras dan air kelapa lebih cenderung produksi yang terbaik yaitu pada tinggi tanaman pada umur 30, 60 dan 90 HST, jumlah daun umur 60 dan 90 HST, jumlah anakan umur 60, 90 HST dan berat umbi.

mengandung karbohidrat sehingga menyebabkan kandungan unsur hara $\mathrm{N}, \mathrm{P}$ dan $\mathrm{K}$ dalam MOL relatif rendah sehingga menyebabkan produksi tanaman belum optimal. Selain itu untuk mendapatkan hasil yang maksimal, tanaman memerlukan unsur hara makro seperti NPK dalam kebutuhan yang cukup, sedangkan pada penelitian ini penggunaan pupuk kimia tidak digunakan sehingga produksinya masih belum optimal.

Tingginya keperluan unsur hara yang dibutuhkan tanaman bawang tiwai sangat mempengaruhi proses metabolisme tanaman. Sesuai dengan pernyataan Redaksi PS (2007) unsur hara merupakan faktor yang mutlak dibutuhkan oleh tanaman untuk melengkapi daur hidupnya, mulai dari fase vegetatif sampai generatif. Unsur-unsur tersebut menjadi bagian dari pertumbuhan tanaman yang penting, karenanya disebut sebagai unsur hara esensial. Namun walaupun tidak berpengaruh nyata pemberian MOL keong mas pada perlakuan P3 menghasilkan hasil jumlah umbi dan berat umbi tertinggi yaitu 11,25 dan 89,42 gram/tanaman.

Hasil analisis sidik ragam menunjukkan bahwa perlakuan MOL keong mas tidak berpengaruh nyata terhadap parameter $\mathrm{pH}$ tanah (media tanam). Hal ini diduga karena $\mathrm{pH}$ tanah 
sebelum diberikan perlakuan MOL keong mas sudah dalam keadaan kategori netral sesuai dengan data awal sebelum perlakuan MOL keong mas. Sehingga ketika tanah diberikan MOL tidak memberikan reaksi yang signifikan

\section{Pengaruh Kombinasi Perlakuan Media Tanam dan Mikroorganisme Lokal (MOL) Keong Mas.}

Hasil sidik ragam menunjukkan bahwa pengaruh interaksi berbagai media tanam dan mikroorganisme lokal (MOL) keong mas tidak berpengaruh nyata terhadap seluruh parameter yang diamati. Tidak adanya pengaruh nyata ini karena perlakuan berbagai media tanam dan MOL keong mas, karena kedua perlakuan

\section{KESIMPULAN}

1. Perlakuan berbagai media tanam tidak berpengaruh nyata terhadap parameter tinggi tanaman $(\mathrm{cm})$, jumlah anakan, jumlah umbi pertanaman (rumpun), berat umbi pertanaman (rumpun) dan $\mathrm{pH}$ media tanam, namun berpengaruh nyata terhadap parameter jumlah daun 60 HST (umur 2 bulan).

\section{DAFTAR PUSTAKA}

Badan Perencanaan dan Pembangunan Daerah Kota Samarinda. Potret Kota Samarinda, keadaan Geografis dan Iklim. Samarinda. Bappeda Kota Samarinda.

Hardjowigeno, S. 2007. Ilmu Tanah. Akademika Presindo. Jakarta.

Kuntorini, E.M. 2013. Kemampuan Antioksidan Bulbus Bawang Dayak (Eleutherine americana) Pada Umur Berbeda. Prosiding Semirata FMIPA Universitas Lampung, 2013.

Laporan Pengembangan Wilayah, 1999. Analisis Data Pokok Untuk Pembangunan Wilayah Propoinsi Kalimanatan Timur, Badan Pengkaji Teknologi Pertanian (BPTP) Prop. Dati Kalimantan Timur. Samarinda.

Mulyono. 2014. Membuat MOL dan Kompos dari Sampah Rumah Tangga. PT.Agromedia Pustaka. Jakarta.

Redaksi PS.2007. Media Tanam untuk Tanaman Hias. Penebar Swadaya. Jakarta. dalam menaikkan $\mathrm{pH}$ tanah. Hal ini dapat dilihat dari data $\mathrm{p} 0, \mathrm{p} 1$ dan $\mathrm{p} 2$ sebelum perlakuan, $\mathrm{pH}$ tanah menunjukkan pada nilai 6,55 begitu pada perlakuan p3 yaitu 6,62 (kriteria netral).

tersebut bertindak bebas antara satu dengan lainnya, media tanam lebih berperan memperbaiki sifat fisik tanah dan tempat berpijaknya tanaman. Ditambahkan oleh Steel dan Torie (1991) apabila interaksi antara perlakuan yang satu dengan yang lain tidak berpengaruh nyata, maka dapat disimpulkan bahwa faktor-faktor tersebut bertindak bebas satu sama lain, pengaruh sederhana suatu faktor sama pada semua taraf faktor lainnya.

2. Perlakuan Mikroorganisme Lokal (MOL) keong mas tidak berpengaruh nyata terhadap seluruh parameter yang diamati yaitu tinggi tanaman, jumlah daun, jumlah anakan, jumlah umbi pertanaman (rumpun), berat umbi pertanaman (rumpun) dan $\mathrm{pH}$ media tanam.

Saptowalyono, C.A., 2008. "Bawang Dayak, Tanaman Obat kanker yang Belum Tergarap”, Palangkaraya, 2007, 31 Oktober 2008, pk. 20.28, hal 1.

Suroto HS, Eldha S, Fitriani dan Murniati, 2006. Studi Karakteristik Fisika kimia Bawang Tiwai dengan Metode Ekstrasi. Balai Riset dan Standarisasi Industri samarinda.

Steel, R. G. D dan J. H. Torrie. 1991. Prinsip dan Prosedur Statistika Suatu Biometric Terjemahan Bambang Sumantri. Gramedia Pustaka. Jakarta.

Sutedjo, M.M., 2008. Pupuk dan Cara Pemupukan. Rineka Cipta. Jakarta.

Tambunan, W. A., Rosita S., dan Ferry E.S. 2014. Pertumbuhan Dan Produksi Bawang Merah (Allium Ascalonicum L.) Dengan Pemberian Pupuk Hayati Pada Berbagai Media Tanam. Jurnal Online Agroekoteknologi . ISSN No. 2337- 6597 Vol.2, No.2 : 825 - 836, Maret 2014. Fakultas Pertanian USU. Medan. 